\title{
ANALYSIS OF THE VARIABILITY OF REGISTERED CASES OF LYME DISEASE AMONG WORKERS OF PRIVATE AGRICULTURE IN WEST POMERANIAN VOIVODSHIP
}

\author{
ANALIZA ZMIAN ZAPADALNOŚCI NA BORELIOZE \\ PRACOWNIKÓW ROLNICTWA INDYWIDUALNEGO \\ W WOJEWÓDZTWIE ZACHODNIOPOMORSKIM
}

Department of Engineering the Agrotechnic Systems, West Pomeranian University of Technology, Szczecin, Poland

\begin{abstract}
Streszczenie. Na podstawie danych epidemiologicznych, uzyskanych ze stacji sanitarnych dokonano analizy zapadalności na boreliozę w województwie zachodniopomorskim w latach 2005-2014, ze szczególnym uwzględnieniem przypadków boreliozy uznanych za chorobę zawodową u osób pracujących w rolnictwie indywidualnym. W okresie poddanym badaniom stwierdzono ogółem 46 przypadków boreliozy, które w trybie decyzji administracyjnej zostały uznane za patologię zawodową u rolników indywidualnych. Rozkład liczby przypadków orzeczonej choroby zawodowej charakteryzował się tendencją wzrostową, przy przeciętnym rocznym wzroście współczynnika zapadalności na boreliozę wynoszącym 2,38 na 100 tys. osób pracujących w rolnictwie. Uzyskane wyniki wskazują na wzrastające ryzyko wystąpienia boreliozy u osób pracujących w rolnictwie, jednak interpretacja oszacowanych miar narażenia nie jest jednoznaczna. Wynika to z faktu, że obserwowana dynamika zmian stanu epidemiologicznego może być efektem realnego wzrostu narażenia zawodowego w rolnictwie (np. w następstwie zmian środowiskowych) i - co jest bardziej prawdopodobne - efektem kumulatywnego współoddziaływania czynników środowiskowych oraz wzrastającej świadomości rolników i skuteczniejszej diagnostyki medycznej.
\end{abstract}

Key words: Lyme disease, occupational diseases, incidence, working in agriculture. Słowa kluczowe: borelioza, choroby zawodowe, zapadalność, osoby pracujące w rolnictwie.

\section{INTRODUCTION}

Working in agriculture is connected with occurrence of the number of threats resulting from exposure to harmful, dangerous and burdensome factors. These factors generate a defined probability of occurrence of events of accidents and occupational diseases, which is reflected in the legal definition of occupational hazard (Rozporządzenie Ministra Pracy i Polityki Socjalnej z 26 września 1997 r.). It must be noted that a potential possibility of deterioration of farmer's health, resulting from exposure to mentioned factors is conditioned by a specificity of the environment and execution of works in agriculture. The values of accident rates which indicate the downward trends from 1990s, may be assumed as a measure of the

Corresponding author - Adres do korespondencji: Tomasz Stawicki, Department of Engineering the Agrotechnic Systems, West Pomeranian University of Technology, Szczecin, Papieża Pawła VI 1, 71-459 Szczecin, Poland, e-mail: tomasz.stawicki@zut.edu.pl 
commented occupational exposure. Undoubtedly, this is a result of the changes which take place in the conditions of execution of agricultural production with participation of technical measures newer and safer in use and growing awareness of threats. In spite of it, the work in agriculture, in particular in the individual agriculture, is still characterised by a big accidental risk (Puślecki 2006; Ministerstwo Rolnictwa i Rozwoju Wsi 2008). The direction of occurring changes may be concluded pursuant to the analysis of the data by the Agricultural Social Insurance Fund, which has been engaged in the statistics of accidents in agriculture for 1990s. In these data, the attention is drawn by the fact of decreasing the absolute number of events of accidents which are the result of exposure to hazardous factors, classified pursuant to the Agricultural Social Insurance Fund nomenclature to, among others, the group of events like "seizure or hitting by moving machine parts and running over, hitting, seizure by a means of transport in motion" (Kasa Rolniczego Ubezpieczenia Społecznego 2015).

It also results from the registration statistics that occupational diseases are not subject to such a trend, with still growing number of events of infectious and parasitic diseases in this group of diseases. It is necessary to mark that, according to data of the Agricultural Social Insurance Fund from 2005-2014 years, in the overall compensation balance paid on account of the occupational disease, close to $70 \%$ of total number of cases concerned the Lyme disease (Kasa Rolniczego Ubezpieczenia Społecznego 2015).

Pursuant to the Regulation of the Council of Ministers of June 30, 2009 (Rozporządzenie Rady Ministrów z dnia 30 czerwca 2009 r.), the infectious and parasitic diseases constitute the Group No. 26 in the list of occupational diseases and, which is typical, they currently belong to the most often diagnosed occupational pathologies in Poland. The above is indicated by the data of the register of occupational diseases conducted by the Occupational Medicine Institute in Lodz. Pursuant to the registration data, 2351 occupational diseases were diagnosed altogether in 2014 , of which 660 cases referred to the infectious and parasitic diseases $(28.07 \%$ of the participation). In addition, Lyme disease was definitely the most often diagnosed disease in this group (543 cases) - Szeszenia-Dąbrowska et al. (2015). This is to indicate that the group of the persons providing work in agriculture belongs, apart from the group providing work in forest, to the occupational groups particularly exposed to the infection caused by spirochete Borrelia burgdorferi (Kaya et al. 2008; Lewandowska et al. 2013; Zemana and Benesb 2013; Tokarska-Rodak et al. 2014; Yanga et al. 2015). Moreover, the scientific publications (Chmielewski 2002; Lewandowska et al. 2013) draw attention on the fact of endemic presence of ticks within the entire territory of Poland. The universality of exposure to ticks contributes to the risk of both occupational and non-occupational contracting Lyme disease, of which arachnids are vectors. It is reflected in research so far undertaken, discussing epidemiological threats in various regions of Poland, among others in: Warmian-Mazurian (Kocbach 2014), Kuyavian-Pomeranian (Brochocka et al. 2014), Lublin (Cisak et al. 2003) and Wielkopolska (Bilski 2009) Voivodships.

The diagnosis of the status of cases of Lyme disease in the group of individual farmers in West Pomeranian Voivodship and evaluation of obtained results pursuant to the dynamics of changes which took place in this respect within 2005-2014 was found in own studies as advisable. Taken issues of research is not new, however it is still relevant and can constitute the valuable supplementation of epidemiological data drawn up for other regions of Poland. 


\section{MATERIAL AND METHODS}

In order to diagnose the status of cases of Lyme disease in West Pomeranian Voivodship and a trend of changes which took place in this respect within 2005-2014, it was applied to the District Sanitary and Epidemiological Stations to obtain the information in the extent of general number of the cases of Lyme disease with their division into quarterly periods and the data referred to the number of Lyme disease which were accepted as the occupational disease of individual farmers in the form of administrative decision. From the overall number of registered cases of infection with the Borrelia burgdorferi, the incidence of Lyme disease in relation to the population of individual districts of the West Pomeranian Voivodship was determined (the data population was provided by the Central Statistical Office). However, elaborating data on cases of the Lyme disease regarded as the occupational disease of individual farmers required setting the number of the exposed people.

The number of sample size of persons exposed to bites by ticks during execution of agricultural works was adopted pursuant to the data of the Central Statistical Office. These data correspond to the number of persons working in agriculture within the area of West Pomeranian Voivodship which was determined pursuant to the methodology used by the World Health Organisation used also in censuses. Pursuant to the mentioned methodology, a person providing work in agriculture is considered as the person at the age of 15 or more and who, in the week preceding the examination executed any profitable work in own (or leased) farm or helped, free of charge, to other family members to conduct a family farm (Główny Urząd Statystyczny 2013). The number of cases of the occupational disease among the workers of the risk group was determined pursuant to the data obtained from the District Sanitary and Epidemiological Stations of West Pomeranian Voivodship, where the occurrence of the cases of Lyme disease among individual farmers was diagnosed in the course of adjudication proceedings.

There is an obligation to notify occupational diseases by the District Sanitary and Epidemiological Stations (Rozporządzenie Rady Ministrów z dnia 30 czerwca 2009 r.) in the course of judicial proceedings appropriate under the place of execution of work. In the case of individual farmers this corresponds basically to the place of residence. In connexion with this, on the basis of obtained data from the District Sanitary and Epidemiological Stations there was a possibility to analyse and evaluate the epidemiological status in the area of West Pomeranian Voivodship and its particular districts.

Collected epidemiological data were subjected to a statistical analysis including the absolute number of cases of infection, in particular on the base of Lyme disease incidences determined according to the relation:

$$
\text { incidence proportion }=\frac{n}{k} \cdot 100000
$$

where:

$n$ - the number of cases in the particular time interval,

$k-$ the size of the population of exposed persons. 
In evaluating the population risk of Lyme disease incidence, the $n$ parameter corresponds to total registered cases of Borrelia burgdorferi infection in the West Pomeranian Voivodships and its individual districts. In this case the $k$ parameter corresponds to the population (of the province or the given district). However, when assessing the risk of infection with the Lyme disease amongst employed in farming, the $n$ parameter corresponds to the number of cases declared as occupational disease of individual farmers of the West Pomeranian Voivodships. In this case the number of occupational diseases is related to the number of people working in farming of the West Pomeranian Voivodships.

When elaborating the research results the obtained epidemiological data were also referenced to nationwide statistics. For depicting the state of the epidemiology of the Lyme disease in the country, data concerning insurance claims paid by the Agricultural Social Insurance Fund to policy holders, which suffered the damage to health as a result of the stated occupational disease, were used.

\section{RESULTS AND DISCUSSION}

The data obtained from the District Sanitary and Epidemiological Stations (20 units) enabled aiming to evaluate the epidemiological status of the cases of Lyme disease in West Pomeranian Voivodship. All the cases of disease, diagnosed and reported to the District Sanitary and Epidemiological Stations were subject to analysis. Figure 1 shows the distribution of the disease cases from years covered by the analysis and divided into the quarterly periods. Growing number of the cases of registered infections by spirochete Borrelia burgdorferi draws attention in the table made - in particular the growth within two last years covered by the study. It corresponds with a general trend of growth of the tick-borne threats observed in the range of the entire Poland (Stefanoff et al. 2006; Kmieciak et al. 2016).

Moreover, it was found a coincidence of obtained results with the literature data (Wójcik-Fatla et al. 2009; Mucha et al. 2012) which demonstrate that the peak of the cases of Lyme disease takes place in summer and autumn months. The combined share of incidences in the third and fourth quarters amounted to the $27 \%$ and the $38 \%$ of all registered cases in 2005-2014 years. Peak of incidences for the last quarters of single years covered by analysis could be associated to the activity of tics and the behavior of individuals exposed to their bites. Attention is drawn in literature to the fact that the activity of tics increased in summer months (Brochocka et al. 2005), i.e. in the period when climatic conditions encourage recreational activities. In addition, the summer months are intended mainly for holiday leaves.

The result of above mentioned conditions is a temporary rise in the number of people exposed to bites of tics. Taking into account the latent period till characteristic disease manifestations of Lyme borreliosis occur, which in the case of erythema is usually from 1 to 3 weeks since a bite (Koperwas 2012), it points at non-random distribution of the examined variable in the years analyzed. However, it should be noted that the schedule of cases of Lyme disease is not subject to the strict seasonal relationship but refers, with varying intensity, to the entire calendar year. It was noted in the analyzed period that the maximum participation of cases in third and fourth quarters was $78 \%$ in 2006 and 2013 , but only $50 \%$ of all incidents in 2010 . The commented findings show the increasing risk of falling ill, especially in two last years of the 
examined period. Such a state of affairs can result in part from the fact of the growing awareness of tick-borne threats which was promoted by information campaigns promoted in the last years that brought attention to the problem of increasing incidence of Lyme borreliosis.

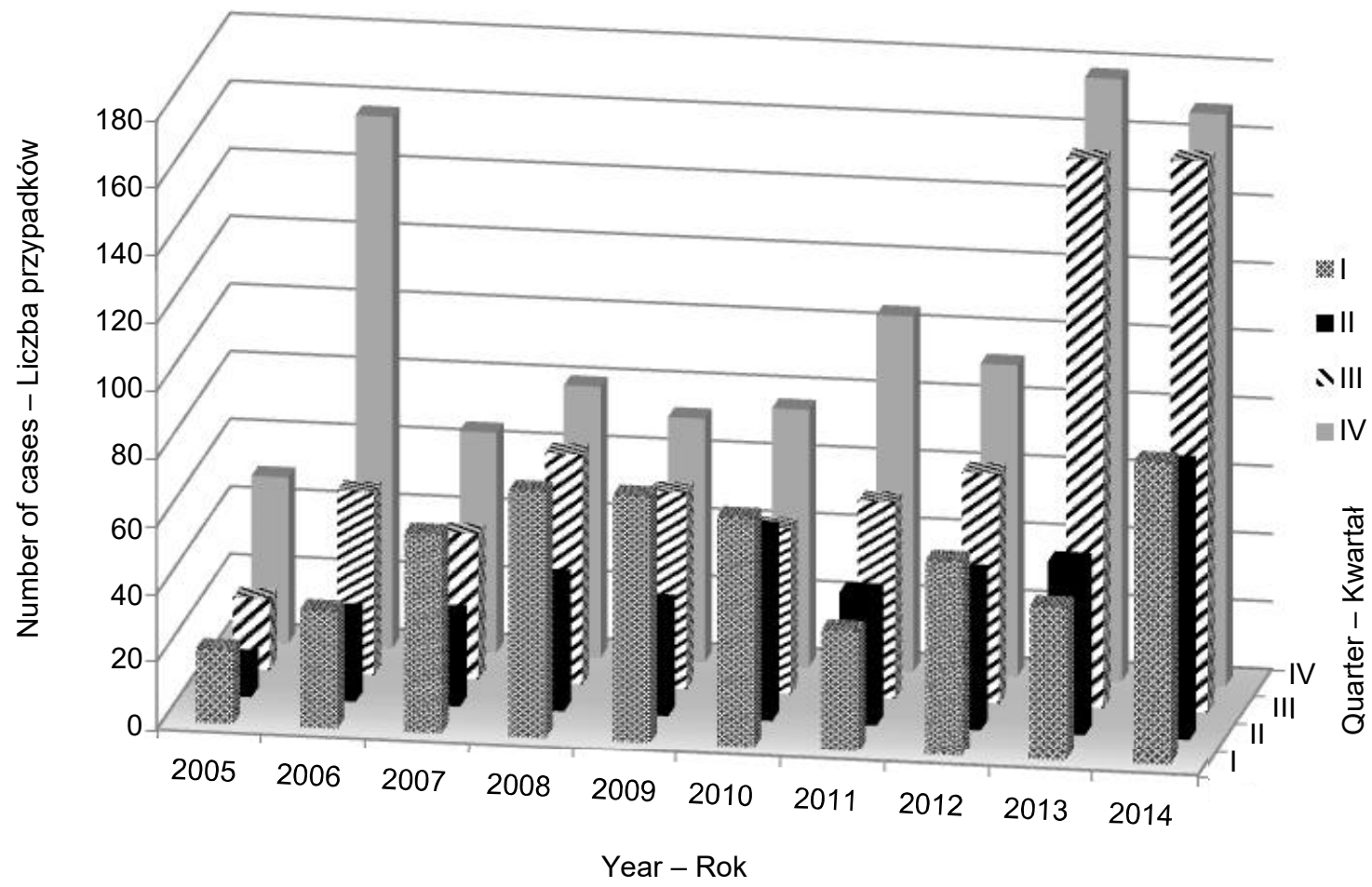

Fig. 1. Cases of Lyme disease of West Pomeranian Voivodship residents within 2005-2014 with their quarterly distribution taken into consideration

Ryc. 1. Przypadki zachorowań na boreliozę mieszkańców województwa zachodniopomorskiego w latach 2005-2014, z uwzględnieniem ich kwartalnego rozkładu

The risk of occurrence of Lyme disease among the individual farmers from the area of West Pomeranian Voivodship was concluded on the basis of the number of cases of Lyme disease which were diagnosed as the occupational disease in the form of the administrative decision.

The statistics of distribution of the examined variable are shown in Table 1 listing the data on farmers sex in respect of whom the District Sanitary and Epidemiological Stations adjudicated the occupational disease. Out of 46 recognized cases of the occupational disease $63 \%$ concerned men. Assuming the same percentage of men and women in the total number of employees in individual farming (the lack of statistics), a higher risk for Lyme disease is in the group of male employees. Above can result from the nature of the work carried out by men (e.g. field cultivation, mowing the lawn, processing the straw and others) which are associated with increased professional exposure to ticks. Pursuant to methodological assumptions, the tabular data were used to determine the trend of changes of the value of incidences to Lyme disease among the persons providing work in agriculture within 2005-2014 (Fig. 2, curve 1). Obtained results were confronted incidences of Lyme diseases in relation to the number of all cases of infection by spirochete Borrelia burgdorferi registered in a given calendar year per one hundred thousand of residents of West Pomeranian Voivodship (Fig. 2, curve 1). The 
course of received characteristics shows the growing risk of infections of Lyme disease and also the growth of registered cases of Lyme disease diagnosed as the occupation disease among individual farmers.

Table 1. Lyme disease in Western Pomerania in selected group of employees in individual farming. Occupational disease cases confirmed in 2005-2014 years

Tabela 1. Borelioza w województwie zachodniopomorskim u osób pracujących w rolnictwie indywidualnym. Przypadki orzeczonej choroby zawodowej w latach 2005-2014

\begin{tabular}{|c|c|c|c|c|c|c|}
\hline \multirow{3}{*}{$\begin{array}{l}\text { Years } \\
\text { Lata }\end{array}$} & \multicolumn{6}{|c|}{$\begin{array}{c}\text { Medical statistics } \\
\text { Statystyka zachorowań }\end{array}$} \\
\hline & \multicolumn{2}{|c|}{$\begin{array}{c}\text { men } \\
\text { mężczyźni }\end{array}$} & \multicolumn{2}{|c|}{$\begin{array}{l}\text { women } \\
\text { kobiety }\end{array}$} & \multicolumn{2}{|c|}{$\begin{array}{l}\text { total } \\
\text { ogółem }\end{array}$} \\
\hline & $\mathrm{n}$ & $\%$ & $\mathrm{n}$ & $\%$ & $\mathrm{n}$ & $\%$ \\
\hline 2005 & - & - & - & - & - & - \\
\hline 2006 & 1 & 3.4 & - & - & 1 & 2.2 \\
\hline 2007 & 1 & 3.4 & - & - & 1 & 2.2 \\
\hline 2008 & - & - & 2 & 11.8 & 2 & 4.4 \\
\hline 2009 & 3 & 10.3 & 2 & 11.8 & 5 & 10.9 \\
\hline 2010 & 2 & 6.9 & 3 & 17.6 & 5 & 10.9 \\
\hline 2011 & 6 & 20.6 & 2 & 11.8 & 8 & 17.4 \\
\hline 2012 & 4 & 13.8 & 3 & 17.6 & 7 & 15.2 \\
\hline 2013 & 7 & 24.1 & 2 & 11.8 & 9 & 19.5 \\
\hline 2014 & 5 & 17.2 & 3 & 17.6 & 8 & 17.4 \\
\hline $\begin{array}{c}\text { Total } \\
\text { Łącznie }\end{array}$ & 29 & 100 & 17 & 100 & 46 & 100 \\
\hline
\end{tabular}

Source: author's analysis on the basis of data acquired from District Sanitary-Epidemiological Stations.

Źródło: opracowano na podstawie danych powiatowych stacji sanitarno-epidemiologicznych.

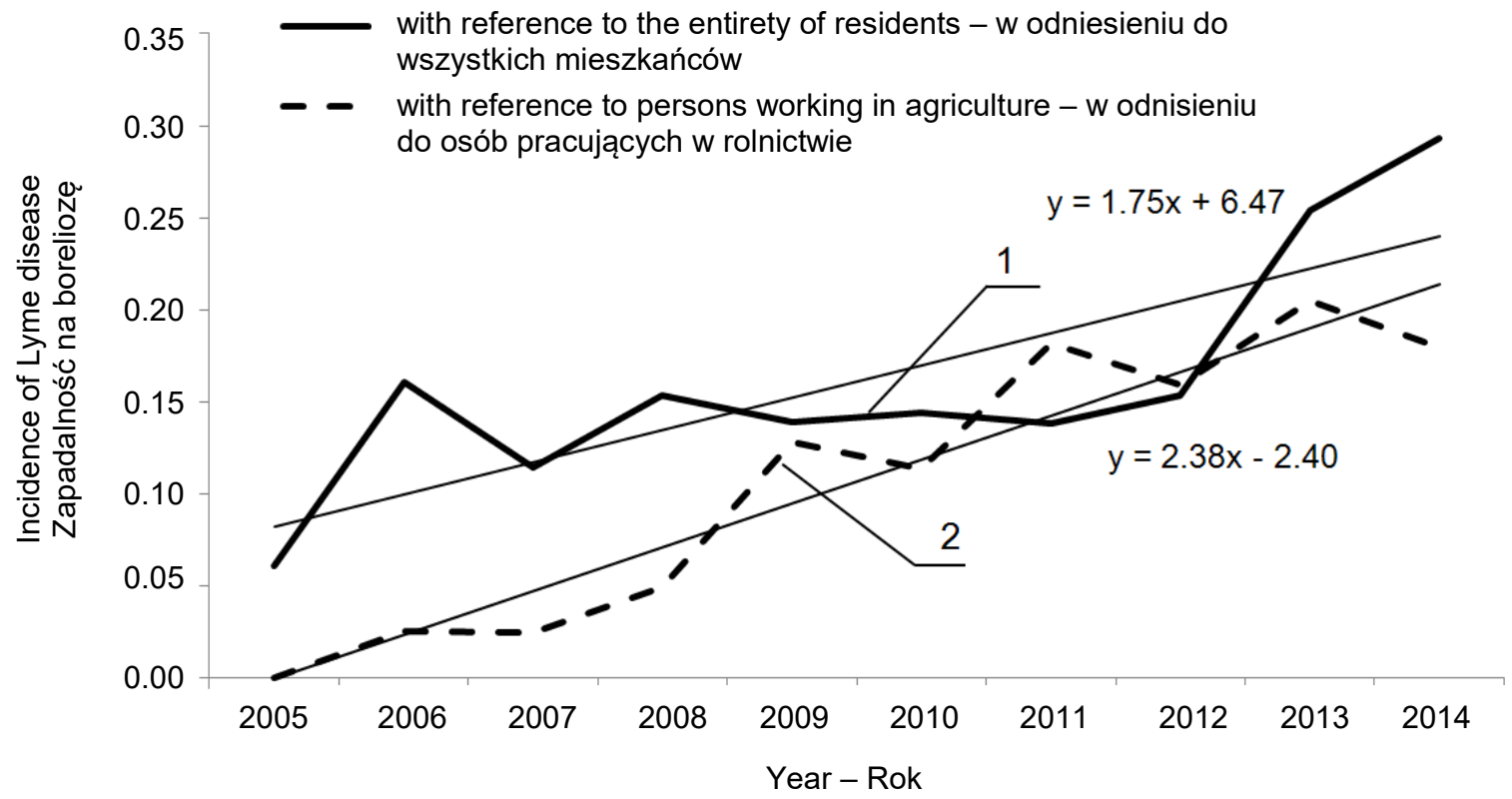

Fig. 2. Incidence to Lyme disease in Western Pomeranian Voivodship in the 2005-2014 years: 1 - incidence per 100000 residents 2 - characteristics of incidence taking into consideration cases of occupational disease confirmed per 100000 working in agriculture

Ryc. 2. Zapadalność na boreliozę w województwie zachodniopomorskim w latach 2005-2014: 1 - zapadalność na 100 tys. mieszkańców, 2 - charakterystyka zapadalności ujmująca stosunek przypadków orzeczonej choroby zawodowej na 100 tys. pracujących w rolnictwie 
It results from the comparison of the values of direction coefficients that the risk of occurrence of the occupational pathology among the persons providing work in agriculture is of the higher dynamics: the growth of incidence by 2.38 per year towards the value of 1.75 for the population of West Pomeranian Voivodship. It is worth underlining the fact that the trend line is better suited for data concerning incidence of Lyme borreliosis in the individual farming. It can result from underlined in scientific studies (Stand 2011) of enhanced knowledge about etiology of Lyme disease, as well as increasing awareness of farmers about the possibility to obtain claim compensation, in the case of damage to health as a result of this illness. For employees in farming factors mentioned could appear cumulatively along with the observed climate changes, such as the increase in the average annual air temperature. Exemplary, that increase for Szczecin in 2001-2008 years was $0.6^{\circ} \mathrm{C}$ in relation to $1991-2000$ years (Michalska 2011). Higher temperatures stimulate an increase in tick population, and in consequence generally higher risk of infection.

It may also be concluded in the result of comparison of characteristics 1 and 2 (Fig. 2) that within the last years covered by the analysis (the years 2013-2014) they approach each other what may suggest that there is lack significance difference between the occupational exposure of farmers and the population risk expressed by the coefficient of incidence for the entirety of residents of West Pomeranian Voivodship.

However, such a concluding seems to be a too far-reaching simplification. It must be taken into consideration that the obligation to perform preventive medical examinations of the health condition is not provided by law in case of individual farmers - which refers to the entirety of the persons providing work in the private sector. A consequence of such a state of affairs may be the reason of relatively low level of awareness of agricultural occupational diseases raised in the literature on this subject (Podstawka 2011; Szewczyk 2012) in relation to the real exposure present in agriculture. The above is confirmed by the results of the research, in which was indicated a higher risk of occurrence of incidence to Lyme disease in the group of individual farmers in comparison to the comparative group of persons not exposed occupationally to ticks (Cisak et al. 2003; Tokarska-Rodak et al. 2014). On the basis of literature review and the authors' own scientific examinations it is difficult clearly to decide in what extent the observed dynamics of changes in epidemiological status is an effect of a real increase in occupational exposure or in which it results from the growing awareness of farmers and the more effective medical diagnosis.

On the basis of the acquired data, it was performed the analysis of the epidemiological status in West Pomeranian Voivodship taking into consideration the entirety of registered incidents of Lyme disease in its particular districts and the number of the cases of Lyme disease diagnosed as occupational disease of individual farmers from these districts (Fig. 3). The comparison of analyzed variables does not indicate a dependence between the number of cases of Lyme disease in a given district and the frequency of diagnosing of Lyme disease as the occupational disease. In years analyzed, at a level of West Pomeranian Voivodship, in total, 2756 cases of infections were registered. The fact that $27.6 \%$ share ( 761 cases) in the structure of these events had a place in the Szczecin district draws attention. It may be connected with the biggest number of residents (almost $24 \%$ in the Voivodship) and a bigger access to health care institutions in participation of which Lyme disease was diagnosed in the course of medical prevention. At the same time, there only twice Lyme disease was approved 
as agricultural occupational disease in the Szczecin district. Within the period of study, Lyme disease was not once diagnosed as the occupational disease in Districts of Gryfice, Koszalin, Pyrzyce, Sławno and Świdwin. On the other hand, in case of Districts of Gryfino and Myślibórz, 7 such cases were diagnosed in both districts, which is the largest registered number of these cases.

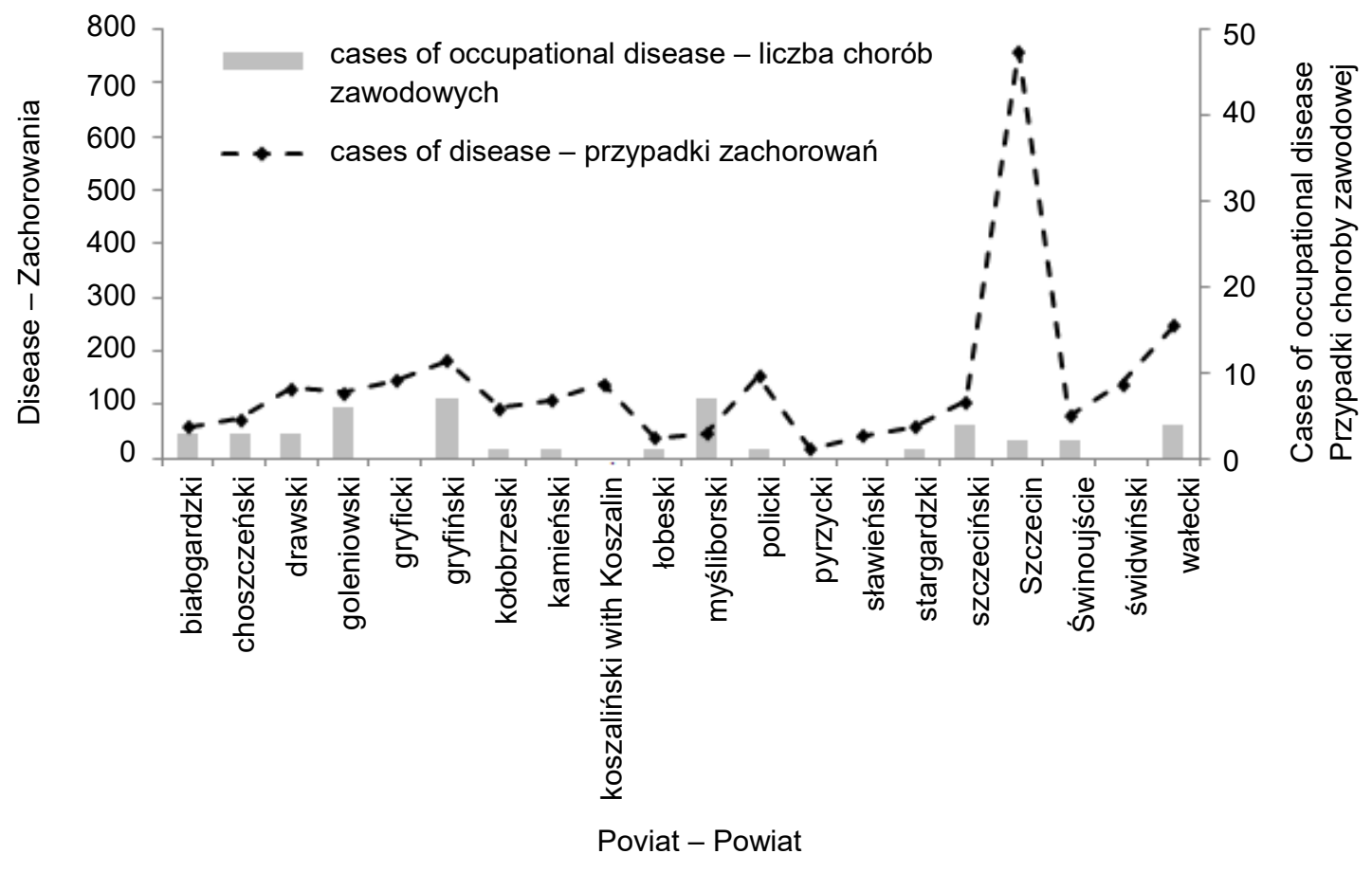

Fig. 3. Cases of Lyme disease in particular districts of West Pomeranian Voivodship. The accumulated data of 2005-2014

Ryc. 3. Zachorowania na boreliozę w poszczególnych powiatach województwa zachodniopomorskiego. Dane skumulowane $z$ lat 2005-2014

A certain obstacle to a direct reference of the results of own studies to the data mentioned is the fact that at determining the values of the accidental coefficients and the frequency of occurrence of occupational diseases in individual farming, the Agricultural Social Insurance Fund takes into consideration the number of insured persons. On the other hand - in the own studies all the cases of the diagnosed occupational disease were taken into consideration, where the particular District Sanitary and Epidemiological Stations settled in the course of adjudication proceedings that they are referred to persons working in agriculture. Moreover, in the Agricultural Social Insurance Fund developments the attention is drawn mainly on the cases of insurance events, which in relation to occupational diseases means the number of one-time compensations paid for detriment to health borne in the result of such diseases. Thereby, at determination of the coefficient of incidence, the Agricultural Social Insurance Fund omits the cases rejected for: lack of entitlements (person uninsured), conclusion of lack of detriment to health and failure to meet obligations by the insured person. In further analysis it was decided to simplify the methodological and indirect reference of the own studies to the Agricultural Social Insurance Fund data to evaluate the risk of occurrence of Lyme disease among persons working in agriculture of West Pomeranian Voivodship against the background of the situation in Poland. 
Within 2005-2014, the Agricultural Social Insurance Fund recognised 36 cases of occupational diseases as fulfilling the criteria resulting in the payment of one-time compensation in West Pomeranian Voivodship. Assuming $70 \%$ participation of Lyme disease in occupational diseases, thus similarly to the entire country within 2005-2014 (Kasa Rolniczego Ubezpieczenia Społecznego 2015), this means 25 cases, on the average approximately 2.5 per year. Simultaneously, within 2005-2015 the Agricultural Social Insurance Fund qualified 1180 cases of Lyme disease as fulfilling the conditions of the compensation benefit across the country, which means the average of 118 cases per year. The determined values do not provide the basis to evaluate the risk of occurrence of Lyme disease in West Pomeranian Voivodship and in the country. It requires to refer the results to the number of persons insured in the Agricultural Social Insurance Fund within 2005-2014, which means the average of 34400.00 in West Pomeranian Voivodship and 1538500.00 within the country. Having the above taken into consideration, there were received the values of the incidences of Lyme disease 7.27 and 7.67 to one hundred thousand insured in West Pomeranian Voivodship and in Poland accordingly. It appears that the risk of incidence of Lyme disease in individual agriculture of West Pomeranian Voivodship does not differ basically from the population risk determined for all the insured in the Agricultural Social Insurance Fund in Poland. Naturally, this does not exclude the occurrence of the essential, area differentiation of incidence to Lyme disease in particular regions of the country.

This is indicated by the data developed on the basis of the statistics of the occupational disease register (Pracownia Badań i Doradztwa "Re-Source" Korczyński Sarapata 2012) which encompass incidence of occupational diseases in Poland within 2005-2011, among others with parasitic and infectious diseases taken into consideration, with leading participation of Lyme disease among them. For example, there were demonstrated the following absolute numbers of registered parasitic and infectious diseases: 58 cases in West Pomeranian Voivodship, 109 cases in Podlaskie Voivodship (the biggest incidence) at the minimum incidence in Opolskie Voivodship (1 case). Not taking polemics over the reasons of territorial differentiation of the incidence to particular disease units, this is to emphasise the fact of growing participation of Lyme disease among the occupational pathologies registered in individual agriculture. Such a state of affairs justifies a need to analysis and further control of the epidemiological status of Lyme disease, especially in relation to the occupational groups of particular risk.

\section{CONCLUSIONS}

The performed analysis of the status of incidence to Lyme disease among persons providing work in agriculture of West Pomeranian Voivodship provides the basis to the following conclusions:

1. The observed trend to the growth of registered incidences of Lyme disease in 2005-2014 years indicates of possibilities of real growth in incidence risk within the analyzed risk group.

2. The coefficient of incidence to Lyme disease determined on the basis of the District Sanitary and Epidemiological Stations data taking into consideration all the cases of the diagnosed occupational disease should be considered as more useful by their reference to the number of persons providing work in agriculture than the coefficient based on the number of compensating benefits paid. 


\section{REFERENCES}

Bilski B. 2009. Occurrence of cases of borreliosis certified as an occupational disease in the province of Wielkopolska (Poland). Ann. Agric. Environ. Med. 16, 211-217.

Brochocka A., Błażejewicz-Zawadzińska M., Kasprzak J., Lisińska J., Barczak T. 2014. Przypadki zachorowań na boreliozę z Lyme w województwie kujawsko-pomorskim w latach 2000-2005 [The cases of incidences of Lyme disease in Kuyavian-Pomeranian Voivodship in 2000-2005 years]. Probl. Hig. Epidemiol. 95(1),143-148. [in Polish]

Cisak E., Chmielewska-Badora J., Zwoliński J., Dutkiewicz J., Patorska-Mach E. 2003. Ocena częstości zakażeń wirusem kleszczowego zapalenia mózgu i krętkami Borrelia burgdorferi wśród rolników indywidualnych na terenie Lubelszczyzny [The evaluation of the frequency of infections by the virus of the tick-borne encephalitis and spirochete Borrelia burgdorferi among individual farmers in the Lublin region]. Med. Pr. 54(2),139-144. [in Polish]

Chmielewski T., Tylewska-Wierzbanowska S. 2002. Występowanie przeciwciał swoistych dla Borrelia burgdorferi u ludzi zdrowych na terenie Polski [The presence of antibodies specific for Borrelia burgdorferi among healthy people in Poland]. Prz. Epidemiol. 56, 33-38. [in Polish]

Główny Urząd Statystyczny. 2013. Aktywność ekonomiczna ludności Polski w latach 2008-2011, http://stat.gov.pl/cps/rde/xbcr/gus/pw_aktywnosc_ekonomiczna_ludnosci_2008-011.pdf, access: 10.09.2016. [in Polish]

Kasa Rolniczego Ubezpieczenia Społecznego. 2015. Wypadki przy pracy i choroby zawodowe rolników oraz działania prewencyjne KRUS w 2014 roku, http://www.krus.gov.pl/fileadmin/ /moje_dokumenty/obrazki/broszury_prewencja/2015/Wypadki_przy_pracy_2015_vp4.pdf, access: 30.08.2016. [in Polish]

Kaya A.D., Parlak A.H., Ozturk C.E., Behcet M. 2008. Seroprevalence of Borrelia burgdorferi infection among forestry workers and farmers in Duzce, north-western Turkey. New Microbiol. 31(2), 203-209.

Kmieciak W., Ciszewski M., Szewczyk E. M. 2016. Choroby odkleszczowe w Polsce - występowanie i trudności diagnostyczne [Tick-borne diseases in Poland - occurrence and diagnostic difficulties]. Med. Pr. 67(1), 73-87. [in Polish]

Kocbach P.P., Kocbach B.P. 2014. Ocena częstości występowania boreliozy wśród pracowników leśnictwa [Frequency evaluation of incidences Lyme diseases among forestry workers]. Med. Pr. 65(3), 335-341. [in Polish]

Koperwas Z. 2012. Borelioza - niebezpieczna choroba z Lyme. Ogólna charakterystyka i diagnostyka laboratoryjna zakażenia, http://laboratoria.net/artykul/15100.html, access: 01.02.2017. [in Polish]

Michalska B. 2011. Tendencje zmian temperatury powietrza w Polsce [Tendency in changes of air temperature in Poland]. Pr. Stud. Geogr. 47, 67-75. [in Polish]

Lewandowska A., Kruba Z., Filip R. 2013. Epidemiology of Lyme disease among workers of forest inspectorates in Poland. Ann. Agric. Environ. Med. 20(2), 329-331

Ministerstwo Rolnictwa i Rozwoju Wsi. 2008. Bezpieczeństwo i higiena pracy w rolnictwie - przegląd dorobku i rekomendacje dla polityki w tym zakresie, https://bip.minrol.gov.pl/content/download/ /28876/157958/.../1/.../BHP_ekspert.pdf, access: 05.09.2016. [in Polish]

Mucha D., Zielazny P., Karakiewicz B. 2012. Choroby przenoszone przez kleszcze - sytuacja epidemiologiczna w województwie pomorskim [Tick-borne diseases - epidemiological situation in Pomeranian Voivodship]. Med. Ogól. Nauk. Zdrow. 18(2), 93-99. [in Polish]

Podstawka M. 2011. Rolnicze choroby zawodowe oraz działania prewencyjne KRUS [Agricultural occupational diseases and the Agricultural Social Insurance Fund preventive measures]. Zesz. Nauk. Uniw. Przyrod.-Humanist. Siedl., Administracja i Zarządzanie 91, 9-18. [in Polish]

Pracownia Badań i Doradztwa "Re-Source" Korczyński Sarapata. 2012. Analiza porównawcza dotycząca przyczyn chorób zawodowych mająca na celu określenie dynamiki zmian w tym zakresie wraz z określeniem rekomendacji dotyczących działań prewencyjnych, http://www.zus.pl/files/dpir/ /Choroby_zawodowe_analiza.pdf, access: 07.09.2016. [in Polish] 
Puślecki D. 2006. Zjawisko wypadkowości w rolnictwie [A phenomenon of accidents in agriculture]. Rocz. Nauk. Stow. Ekon. Rol. Agrobiz. 8(4), 291-296. [in Polish]

Rozporządzenie Ministra Pracy i Polityki Socjalnej z 26 września 1997 r. w sprawie ogólnych przepisów bezpieczeństwa i higieny pracy. DzU z 2003 r., nr 169, poz. 1650. [in Polish]

Rozporządzenie Rady Ministrów z dnia 30 czerwca 2009 r. w sprawie chorób zawodowych. DzU z 2009 r., nr 105, poz. 869. [in Polish]

Stefanoff P., Rosińska M., Zieliński A. 2006. Epidemiologia chorób przenoszonych przez kleszcze w Polsce [Epidemiology of tick-borne diseases in Poland]. Prz. Epidiol. 60, 151-159. [in Polish]

Szeszenia-Dąbrowska N., Wilczyńska U., Sobala W. 2015. Choroby zawodowe w Polsce w 2014 r. Łódź, Inst. Med. Pr. im. prof. J. Nofera. [in Polish]

Szewczyk H. 2012. Rolnicze choroby zawodowe i para zawodowe [Agricultural occupational and paraoccupational diseases]. Wieś Rol. 3(156), 97-112. [in Polish]

Tokarska-Rodak M., Plewik D., Kozioł-Montewka M., Szepeluk A., Paszkiewicz J. 2014. Ryzyko zakażeń zawodowych Borrelia burgdorferi u pracowników leśnictwa i rolników [The risk of occupational infections Borrelia burgdorferi among forestry workers and farmers]. Med. Pr. 65(1), 109-117. [in Polish]

Wójcik-Fatla A., Szymańska J., Buczek A. 2009. Choroby przenoszone przez kleszcze. Cz. I. Ixodes ricinus jako rezerwuar i wektor patogenów [Tick-borne diseases. Part I. Ixodes ricinus as reservoir and vector of pathogens]. Zdr. Publ. 119(2), 213-216. [in Polish]

Yanga G.J., Utzingerd J., Zhou X.N. 2015. Interplay between environment, agriculture and infectious diseases of poverty: Case studies in China. Acta Trop. 141, 399-406.

Zemana P., Benesb C. 2013. Spatial distribution of a population at risk: An important factor for understanding the recent rise in tick-borne diseases (Lyme borreliosis and tick-borne encephalitis in the Czech Republic). Ticks Tick-borne Dis. 4, 522-530.

\begin{abstract}
The analysis of incidence to Lyme disease (Borreliosis) in West Pomeranian Voivodship within 2005-2014, in particular with taking into consideration the cases of Lyme disease diagnosed as an occupational disease among the persons providing work in individual agriculture, has been executed pursuant to the epidemiological data obtained from the sanitary stations. In total, 46 cases of Lyme disease were found among individual farmers within the examination period and they were considered as an occupational pathology in the form of an administrative decision. The distribution of the number of cases of diagnosed occupational disease was characterised by the growing trend at the average growth of the coefficient of incidence to Lyme disease per year -2.38 cases to one hundred thousand of the persons working in agriculture. The results obtained indicate the growing risk of occurrence of Lyme disease among the persons working in agriculture, however the interpretation of the estimated measures of exposure is not clear. It results from the fact that observed dynamics of the changes of epidemiological status may result from a real growing of the occupational exposure in agriculture (e.g. in the aftermath of environmental changes) and, which is more probable, from a cumulative synergy of the environmental factors, growing awareness of farmers and more effective medical diagnostics.
\end{abstract}


